\title{
The Myth of How to Interpret the Seventh Amendment Right to a Civil Jury Trial
}

\author{
KENNETH S. KLEIN ${ }^{*}$
}

\section{INTRODUCTION}

So the Emperor went in procession under the rich canopy, and every one in the streets said, "How incomparable are the Emperor's new clothes! what a train he has to his mantle! how it fits him!" No one would let it be perceived that he could see nothing, for that would have shown that he was not fit for his office, or was very stupid. No clothes of the Emperor's had ever had such a success as these.

"But he has nothing on!" a little child cried out at last.

"Just hear what that innocent says!" said the father: and one whispered to another what the child had said.

"But he has nothing on!" said the whole people at length. That touched the Emperor, for it seemed to him that they were right; but he thought within himself, "I must go through with the procession." And so he held himself a little higher, and the chamberlains held on tighter than ever, and carried the train which did not exist at all. 1

The Emperor's story is nothing more than an amusing parable. The parable is unfortunately apt, however, to an anomalous situation under which federal courts and practitioners have been laboring for almost two hundred years. That is the two hundred year old myth regarding the meaning of the Seventh Amendment.

The Seventh Amendment reads:

In Suits at common law, where the value in controversy shall exceed twenty dollars, the right of trial by jury shall be preserved, and no fact tried by a jury, shall be otherwise reexamined in any Court of the United States, than according to the rules of common law. ${ }^{2}$

\footnotetext{
* As a practitioner, there are a variety of pressures to do virtually anything but write an article. This Article could not have been written without the cooperation and support of my firm, Gray, Cary, Ames \& Frye, or the help of the following friends and colleagues: Lynne Dallas, Marcelle Mihaila, Kevin Cole, Marianne Barrett, the Library Staff of Gray, Cary, Ames \& Frye, Mary Stephens, Mary Lehman, Daniel Eaton, Suzanne Tracy, and June MacLeod. The author sincerely thanks each of them. Two persons in particular bear special mention: Lisa Black and Brian Foster.

1 Hans Christian Andersen, The Emperor's Clothes, in FOLK-LORE AND FABLE 238 (C.W. Eliot ed., 1909).

2 U.S. CONST. amend. VII.
} 
For two hundred years, our courts have labored under the myth that this language contains the kernel of a black-letter rule of law. This is the so-called "historical test," which derives from jury practices prevalent under English common law during the eighteenth century. The test specifies a broad class of civil cases for which the right to a jury is purportedly constitutionally guaranteed. In fact, this supposed black-letter rule of law has no more substance than the Emperor's clothes. It is time to put an end to what has proven to be a durable myth of the form of the constitutionally guaranteed right to a jury in civil litigation. ${ }^{3}$

The origins of this myth lie in a philosophical dilemma facing the early Americans of the late eighteenth century. Our Founding Fathers fervently believed that jury trials were not only appropriate, but critically important in civil litigation. They did not believe, however, that a jury was appropriate for all civil cases. The quandary was in defining which class of cases should be tried to a jury. Even though the issue surfaced at the Federal Convention, the state ratification debates, and the First Congress, there was no effort to reach a final resolution. Thus, the result was Seventh Amendment language that, read in its historical context, says little more than jury trials are a good idea and people should have them.

That language inevitably would only defer the problem. The drafters of the Seventh Amendment clearly wanted to guarantee a jury trial in some, but not all, civil cases. The amendment, however, did not define which cases.

This lack of specificity required the courts themselves to define the limits of the Seventh Amendment. The courts' involvement, in turn, resulted in the creation of a theory that was based upon what, in retrospect, was an unwarranted and almost ridiculous leap of faith. That theory is, because the Founding Fathers felt civil jury rights were of paramount importance, and the Seventh Amendment memorializes these views, the Seventh Amendment must carry within its language a black-letter rule of law. Amazingly, since 1812, no American court has ever questioned whether this conclusion follows logically. It does not.

3 To date, while there have been some advocates of a functional approach as a replacement of the historical test, they have almost unanimously hesitated to suggest that the language of the Seventh Amendment actually envisioned a functional approach. See, e.g., David L. Shapiro and Daniel R. Coquillette, The Fetish of Jury Trial in Civil Cases: $A$ Comment on Rachal v. Hill, 85 HARV. L. REV. 442, 449-50 (1971). While one author has written that "[t]he language and purpose of the seventh amendment does not prevent the Supreme Court from adopting a functional, nonhistorical approach both to expand and to contract the right to a civil jury trial" (a conclusion that this Article agrees with), that commentator does not endeavor to support this conclusion with an in-depth analysis of the history of the amendment; and it may be more accurate to say that her comment is an imprecise characterization of a different theme. Mary K. Kane, Civil Jury Trial: The Case for Reasoned Iconoclasm, 28 HASTINGS L.J. 1, 34 (1976). 
The lack of critical analysis has, predictably, led to the creation of a cumbersome system replete with anomalous and inconsistent rules governing jury practice. In assuming the Seventh Amendment contained a black-letter rule of law, courts had to "find" that rule within the text of the amendment. Courts attempted to distill the substance of this supposed rule of law from the literal text of the amendment. The only language in the amendment that could conceivably embody such a rule was the phrase "In suits at common law." Thus, our present federal civil jury practice has in fact evolved out of the historical interpretation of this particular phase. Unfortunately, the result is that our current practices derive from the obsolete and questionable methodology of comparing modern cases to those prevalent in the common law courts of eighteenth century England, as opposed to a structured analysis of the rights juries are intended to preserve, or the advantages or capabilities of the modern jury.

It is time to end this charade. The sooner we confess that both as a matter of original intent and subsequent evolution, the Seventh Amendment is not what we have made of it, the sooner our legal system will address the task of defining civil jury rights in a way that is philosophically and jurisprudentially sound.

\section{II. 'THE HISTORY OF THE SEVENTH AMENDMENT AND HOW IT LED TO SEEMINGLY PRECATORY LANGUAGE}

Comprehensively tracing the history of the Seventh Amendment is an article in itself, and has been tackled on two occasions. ${ }^{4}$ Edith Henderson and Charles Wolfram independently have generated excellent histories of the Seventh Amendment. ${ }^{5}$ The usefulness and integrity of their work is not only confirmed by the congruity of many of their findings, but also by the reliance placed on them by later writers addressing various aspects of the Seventh Amendment. ${ }^{6}$

The history of the Seventh Amendment, as reported by both Henderson and Wolfram, is a story with conflicting textures. It is undisputed that our founders felt that jury rights were of central importance. It is equally clear that they could not agree on the scope of protection to afford those rights.

${ }^{4}$ For a concise, helpful history of the origins of juries in western jurisprudence, see 5 JEREMY C. MOORE, ET AL., MOORE'S FEDERAL PRACTICE \38.02 (1991). See also Jack Pope, The Jury, 39 TEX. L. REv. 426 (1961).

5 Edith Guild Henderson, The Background of the Seventh Amendment, 80 HARV. L. REV. 289 (1966); Charles W. Wolfram, The Constitutional History of the Seventh Amendment, 57 MNN. L. REV. 639 (1973).

${ }^{6}$ See, e.g., Note, Complex Civil Litigation and the Seventh Amendment Right to a Jury Trial, 51 U. CHI. L. REv. 581, 585 (1984); Parklane Hosiery Co. v. Shore, 439 U.S. 322, 337-56 (1979) (Rehnquist, J., dissenting). 
Civil juries were first protected in America in 1641 in the Massachusetts Body of Liberties, section 29,7 and were first constitutionally guaranteed in 1776 in the Virginia Declarations of Rights, section $11 .^{8}$ Indeed, even the Articles of Confederation provided jury rights for some types of cases. ${ }^{9}$ Yet, there is no record that when the founders of this nation convened the Federal Convention, that they gave any appreciable attention to the issue of jury trials. As a result, one of the more remarkable aspects of the Seventh Amendment is the paucity of notes or documents that would indicate the authors of the Constitution and Bill of Rights engaged in any critical analysis of whether and/or when a jury was a good idea in a civil case. ${ }^{10}$

Nevertheless, within the limited documentation available, there are four themes that emerge:

1. A belief that jury trials are appropriate, and perhaps critically important in civil litigation;

2. An assumption that, nonetheless, a right to a jury is not appropriate for all civil cases;

3. A seeming inability to define which cases should have a jury right; and,

4. A resulting attempt to avoid the problem of lack of definition by making vague, imprecise reference to the existing, usual practice.

These themes are critical to understanding the resulting language.

\section{A. The Founders Were Committed to the Concept of Civil Juries}

The comments of our nation's founders in the late eighteenth century provide repeated reference to the importance early Americans placed on civil jury rights. Patrick Henry, speaking in the Virginia Constitutional Convention,

71 THE BLL OF RIGHTS: A DOCUMENTARY HISTORY 75 (Bernard Schwartz ed., 1971).

${ }^{8} I d$. at 235. Civil jury rights were also protected in the Vermont Declaration of Rights of 1777, section XIII, id. at 324; the Pennsylvania Declaration of Rights of 1776, section $\mathrm{XI}, \mathrm{id}$. at 265; the North Carolina Declaration of Rights of 1776, section XIV, id. at 123; the Fundamental Constitutions of Carolina of 1669, section 111, id. at 298; the Georgia Constitution of 1777, articles XL-XLII, id. at 282; the Maryland Declaration of Rights of 1776 , section XXI, id. at 342; the Massachusetts Declaration of Rights of 1780 , section XV, id. at 378; the New Hampshire Bill of Rights of 1783, section XX, id. at 395; the ordinances of the Northwest Territories of 1787, id. at 387; and the Concessions and Agreements of West New Jersey, chapter XXII, id. at 129.

9 Wolfram, supra note 5, at 654-56. In 1787, while the Articles of Confederation were still in place, at least one court ruled that a citizen had a right to a civil jury in any case involving a right to property. Bayard v. Singleton, 1 N.C. (Mart.) 42, 44 (1787).

10 Henderson, supra note 5, at 291; Wolfram, supra note 5, at 657. Although it is theoretically possible that the authors of the Constitution engaged in a great deal of debate about civil jury rights, there is no written record even remotely suggesting that conclusion. 
called civil juries the "best appendage of freedom," one "which our ancestors secured [with] their lives and property."11 Thomas Jefferson, who was in France during the Federal Convention, said, "I consider trial by jury as the only anchor, ever yet imagined by man, by which a government can be held to the principles of it's [sic] constitution." 12 Thomas Paine felt civil juries were an extension of a natural right. ${ }^{13}$ The Federalists opined that eliminating civil jury rights could lead to insurrection. ${ }^{14}$ Indeed, when Alexander Hamilton defended the Constitution's omission of a civil jury trial guarantee, he did not contend that the right was unimportant, but rather that the silence of the Constitution did not impinge upon it. ${ }^{15}$

The states did not share Hamilton's view. When the Constitution went to the states for ratification, it met with immediate concern that it inadequately guarded individual liberties, and in particular that "in civil causes it did not secure the trial of facts by a jury."16 Thus, when Hamilton reflected on the entire range of stated objections to the Constitution, he opined that the one which met with the most success, at least in his state, "and perhaps in several of the other [s]tates, is that relative to the want of a constitutional provision for the trial by jury in civil cases." 17 As Hamilton alludes, the Anti-Federalists, who led the opposition to the Constitution, rallied support by asserting that the Constitution would abolish civil juries altogether. ${ }^{18}$

A wide variety of records emanated from the thirteen states concerning the ratification debates. A detailed discussion of the particulars of those records is not possible in this Article. It is enlightening, however, to consider Ms. Henderson's characterization of the reaction to the draft Constitution:

Within a month the whole country was divided into Federalist and Anti-

Federalist parties. The almost complete lack of any bill of rights was a

113 THE DEBATES IN THE SEVERAL STATE CONVENTIONS ON THE ADOPTION OF FEDERAL CONSTITUTION 324, 544 (Jonathan Elliot ed., 2d ed. 1836) [hereinafter ElLIOT's DEBATES].

1215 The Papers of ThOMAS JefFerson 267 (Julian P. Boyd ed., 1958) (letter to Thomas Paine dated Paris, July 11, 1789). Jefferson would later express surprise at his perception that the populace would give up the right without protest. 12 THE PAPERS OF THOMAS JEFFERSON 557-58 (Julian P. Boyd ed., 1958).

131 THE BILL OF RIGHTS: A DOCUMENTARY HISTORY, supra note 7, at 316.

14 ANSWERS TO MR. MASON'S OBJECTIONS TO THE NEW CONSTITUTION, 1788, reprinted in PAMPHLETS ON THE CONSTITUTION OF THE UNITED STATES 362 (Paul Leicester Ford ed., 1971). 1888).

15 THE FEDERALIST No. 83, 516-32 (Alexander Hamilton) (Henry Cabot Lodge ed.,

16 United States v. Wonson, 28 F.Cas. 745, 750 (C.C.D. Mass. 1812) (No. 16,750).

17 THE FEDERALIST, supra note 15 , at 516-17.

18 Henderson, supra note 5, at 292. "One of the strongest objections originally taken against the Constitution of the United States, was the want of an express provision securing the right of trial by jury in civil cases." Parsons v. Bedford, 3 Pet. 433, 446 (1830). 
principal part of the Anti-Federalist argument; the lack of provision for civil juries was a prominent part of this argument, and the Supreme Court's appellate jurisdiction in law and in fact was treated by the Anti-Federalists as a virtual abolition of the civil jury. ${ }^{19}$

In Pennsylvania, the Anti-Federalists almost prevented the ratifying convention from even occurring, largely because they believed the Federalists were trying to abolish civil juries. ${ }^{20}$ There was similar sentiment in a variety of other states, most notably Massachusetts, New Hampshire, Virginia, New York, and Rhode Island.

Thus, the extant records of the late eighteenth century are apparently unanimous in their expression of the perceived importance of civil jury rights. The only disagreement seems to be over whether civil jury rights were the most important of all individual rights, or simply one of the most important rights.

\section{B. The Founders Did Not Believe That Civil Juries Were Appropriate in All Cases}

In the period of time between the adoption of the Articles of Confederation and the adoption of the Constitution, all thirteen states provided for civil juries in some, but not all cases. A pamphlet responding to Anti-Federalist George Mason's objections to the new constitution reflected, "In respect to the trial by jury in civil cases, it must be observed it is a mistake to suppose that such a trial takes place in all civil cases now. . . . The States in these particulars differ very much in their practice from each other." ${ }^{21}$ In Federalist Paper No. 83, which is one of the most extensive contemporaneous discussions of jury practice in civil cases, Alexander Hamilton provided a stark and detailed description of the vast variety of jury practice among the states:

The great difference between the limit of the jury trial in different States is not generally understood; . . . . In this State, our judicial establishments resemble, more nearly than any other, those of Great Britain. We have courts of common law, courts of probate (analogous in certain matters to the spiritual courts in England), a court of admiralty, and a court of chancery. In the courts of common law only, the trial by jury prevails, and this with some exceptions. In all the others a single judge presides, and proceeds in general either according to the course of the canon or civil law, without the aide of a jury. In New Jersey, there is a court of chancery which proceeds like ours, but neither courts

19 Henderson, supra note 5, at 295.

${ }^{20} \mathrm{Id}$. at 296-97. Mr. Wolfram suggests that this sentiment by the Anti-Federalists may not have been for the pure love of individual liberties, so much as a recognition of a populist issue that would serve their goals. Wolfram, supra note 5, at 667-68.

21 ANSWERS TO MR. MASON'S OBJECTIONS TO THE NEW CONSTTUUTION, 1788, supra note 14 , at 361 . 
of admiralty nor probates, in the sense in which these last are established with us. In that State, the courts of common law have the cognizance of those causes which with us are determinable in the courts of admiralty and of probate, and of course the jury trial is more extensive in New Jersey than in New York. In Pennsylvania, this is perhaps still more the case, for there is no court of chancery in that State, and its common-law courts have equity jurisdiction. It has a court of admiralty, but none of probates, at least on the plan of ours. Delaware has in these respects imitated Pennsylvania. Maryland approaches more nearly to New York, as does also Virginia, except that the later has a plurality of chancellors. North Carolina bears most affinity to Pennsylvania; South Carolina to Virginia. I believe, however, that in some of those States which have distinct courts of admiralty, the causes depending in them are triable by juries. In Georgia, there are none but common-law courts, and an appeal of course lies from the verdict of one jury to another, which is called a special jury, and for which a particular mode of appointment is marked out. In Connecticut, they have no distinct courts either of chancery or admiralty, and their courts of probate have no jurisdiction of causes. Their common-law courts have admiralty, and, to a certain extent, equity jurisdiction. In cases of importance, the General Assembly is the only court of chancery. In Connecticut, therefore, the trial by jury extends in practice further than in any other State yet mentioned. Rhode Island is, I believe, in this particular, pretty much in the situation of Connecticut. Massachusetts and New Hampshire, in regard to the blending of law, equity, and admiralty jurisdictions, are in a similar predicament. In the four Eastern States, a trial by jury not only stands upon a broader foundation than any other States, but it is attended with peculiarity unknown in its full extent, to any of them. There is an appeal of course from one jury to another, til there have been two verdicts out of three on one side. 22

When the topic of civil juries was discussed at the Federal Convention, the lack of uniformity among the states was central in the debate. For example, as James Madison reported the discussion at the Federal Convention, one delegate, Mr. Gorham, noted the difficulty of having a civil jury clause in the Constitution was that "[t]he constitution of Juries is different in different States and the trial itself is usual in different cases in different States."23

Quite obviously, Mr. Gorham's comment accurately reflects that before the convening of the Federal Convention, each of the thirteen states had a different jury practice. The problem went beyond each state's structure of courts (as described by Hamilton), it also extended to procedural mechanisms:

22 THE FEDERALIST, supra note 15, at 523-25 (footnotes omitted).

232 THE RECORDS OF THE FEDERAL CONVENTION OF 1787, 587, 628 (Max Farrand d., 1911). Interestingly, this comment by Gorham and the response by General Pickney ure virtually the only comments about jury rights found in surviving records. One is left to ssume, without really knowing, that the recorded comments were chosen because they rere representative of general sentiment. 
A study of the decided cases in the thirteen original states shows that ... the power of the civil jury and the extent of judicial control over its verdicts varied enormously and unsystematically from state to state. Each of the thirteen colonies, as might be expected, had developed an individual style and emphasis, in part because each had begun borrowing from a slightly different stage of the English historical development. . . . Nearly every procedural device for controlling the civil jury was used somewhere on this side of the Atlantic. $^{24}$

There simply was no consensus among the thirteen states on what civil cases a jury should hear, what the jury's scope of responsibility should be within a case, or what sort of review of juries by judges was appropriate. ${ }^{25}$

\section{The Founders Were Either Unable or Unwilling to Set Forth a Single Rule Defining When Civil Juries Were Appropriate.}

There is an important point of agreement, however, that is apparent from a review of the diversity of practice among the states. All thirteen states recognized juries in some, but not all, civil cases. While each drew the line differently, none empaneled a jury in every case.

Logically, the lack of uniformity of jury practice should have resulted in a great deal of debate at the Federal Convention. An obvious drafting problem existed. If the Constitution were to speak to civil jury rights at all, it would either have to adopt the practices of one single state (thereby endangering ratification in the states whose practice it contradicted) or it would have to somehow attempt to embrace all existing practices. Since neither course was clear or even particularly viable, the issue would seem to require significant attention in order to clarify otherwise muddy waters. ${ }^{26}$

24 Henderson, supra note 5, at 299.

25 See Wolfram, supra note 5, at 660; Galloway v. United States, 219 U.S. 372, 392 (1943). Ironically, England's judicial attitude toward juries was no more coherent. One might expect that when contrasting England to the thirteen states, the role of juries would be better defined, if only because England had one set of courts instead of thirteen. Apparently, it was not. Henderson, supra note 5, at 299; see also Wolfram, supra note 5, at 653.

26 Anti-Federalist Richard Henry Lee would later write, "The trials by jury in civil causes, it is said, varies so much in the several states, that no words could be found for the uniform establishment of it. If so, the federal legislation will not be able to establish it by any general laws. I confess I am of opinion it may be established, but not in that beneficial manner in which we may enjoy it, for the reasons beforementioned." RICHARD HENRY LEE, OBSERVATION LEADING TO A FAIR EXAMINATION OF THE SYSTEM OF GOVERNMENT, 1787, reprinted in PAMPHLETS ON THE CONSTITUTION OF THE UNTEE STATES 315 (Paul Leicester Ford ed., 1971). 
There was no significant discussion. The Federal Convention considered judiciary matters for only six days in the summer of $1787 .{ }^{27}$ The first mention of juries occurred just five days before the Federal Convention was set to adjourn. ${ }^{28}$ The floor discussion lasted less than one hour. ${ }^{29}$ Yet the issue of civil juries was not even touched upon until the Committee on Style and Arrangement reported out "what was nearly the final draft of the Constitution. ... ${ }^{n 30}$

Much of the debate (what little there was) is captured in the records of September 12, 1787:

Mr. Williamson, observed to the House that no provision was yet made for juries in Civil cases and suggested the necessity of it.

Mr. Gorham. It is not possible to discriminate equity cases from those in which juries are proper. The Representatives of the people may be safely trusted in this matter.

Mr. Gerry urged the necessity of Juries to guard agst. corrupt Judges. He proposed that the Committee last appointed should be directed to provide a clause for securing the trial by Juries.

Col. Mason perceived the difficulty mentioned by Mr. Gorham. The jury cases cannot be specified. A general principle laid down on this and some other points would be sufficient. He wished the plan had been prefaced with a Bill of Rights, would second a Motion if made for the purpose - It would give great quiet to the people; and with the aid of the State declarations, a bill might be prepared in a few hours.

Mr. Gerry concurred in the idea \& moved for a Committee to prepare a Bill of Rights. Col. Mason 2ded the motion.

Mr. Sherman. Was for securing the rights of the people where requisite. The State Declarations of Rights are not repealed by this Constitution; and being in force are sufficient - There are many cases where juries are proper which cannot be discriminated. The Legislature may be safely trusted.

Col. Mason. The Laws of the U.S. are to be paramount to State Bills of Rights. On the question for a Come to prepare a Bill of Rights.

27 Henderson, supra note 5, at 292-93.

28 Wolfram, supra note 5, at 657.

${ }^{29} \mathrm{Id}$. at 660 , n.60.

${ }^{30}$ Henderson, supra note 5, at 293. 
N.H. no. Mas. abst. Ct no. N- J- no. Pa. no. Del- no. Md no. Va no. N-C. no. S- C- no - Geo- no. [Ayes - 0; noes - 10; absent - 1. $]^{31}$

Despite the short debate, we know that the tension between the importance of civil juries on the one hand, and the wide diversity of practice on the other hand, was troubling to the delegates of the Federal Convention. Hamilton reports that there was such "material diversity" of practice among the states that "no general rule could have been fixed upon by the convention which would have corresponded with the circumstances of all the States; and secondly, that more or at least as much might have been haphazard by taking the system of any one State for a standard, as by omitting a provision altogether and leaving the matter, as it had been left, to legislative regulation." ${ }^{32}$ While we know-in retrospect-that the delegates to the Convention essentially threw up their hands rather than solve this problem, it is perhaps surprising that they did so without a great deal of discussion or debate.

Ultimately, the Federal Convention's proposed Constitution simply did not speak to civil jury trial rights at all. One recorded comment from the convention reinforces Hamilton's view of why this happened. That comment is from General Pickney (responding to Mr. Gorham), who (according to Madison's notes) argued that given the lack of uniformity of jury practice among the states, a constitutional clause preserving jury rights in civil cases would be "pregnant with embarrassments." 33 This comment certainly suggests that the omission of a civil jury clause was intentional and at least in part related to the inability of the delegates to say what the Constitution should require. ${ }^{34}$

While there is no way to know for sure whether General Pickney's comment was representative of most delegates' opinions (perhaps a significant number of delegates did not agree with the policy choice of the proposed language, perhaps there was apathy, perhaps it was simply a long, hot summer and the convention members wanted to go hom ${ }^{35}$ ), the retrospective comments of other convention delegates give strong reason to think that General Pickney got it right. In a letter to the Marquis de Lafayette in 1788, George Washington explained that civil jury rights were omitted from the Constitution because "it

31 THE RECORDS OF THE FEDERAL CONVENTION of 1787, 587-88 (Max Farrand ed., 1911).

32 THE FEDERALIST, supra note 15 , at 525 .

332 THE RECORDS OF THE FEDERAL CONVENTION OF 1787, supra note 23, at 628; Wolfram, supra note 5, at 665-66. When Pickney reported on the Federal Convention to the ratification debates in South Carolina, he confirmed that the Constitution was silent on civil juries because "they found it impossible to make any precise declaration upon the subject." 4 ELLIOT'S DEBATES, supra note 11, at 260. Randolph took the same position in the Virginia ratification debates. 3 ELLIOT'S DEBATES, supra note 11, at 68.

34 Wolfram, supra note 5, at 665-66.

35 Henderson, supra note 5, at 294-95; see also, Wolfram, supra note 5, at 657, 661. 
was only the difficulty of establishing a mode, which would not interfere with the fixed modes of any of the States, that induced the convention to leave it as a matter of future adjustment." 36 Similarly, in their pamphlets urging adoption of the Constitution, the Federalists defended the silence of the Constitution on civil juries by arguing:

In respect to the trial by jury in civil cases, it must be observed it is a mistake to suppose that such a trial takes place in all civil cases now. Even in the common law courts, such a trial is only had where facts are disputed between the parties, and there are even some facts triable by other methods. In the Chancery and Admiralty Courts, in many of the States, I am told they have no juries at all. The States in these particulars differ very much in their practice from each other. A general declaration therefore to preserve the trial by jury in all civil cases would only have produced confusion, so that the courts afterwards in a thousand instances would not have known how to have proceeded. If they had added, "as heretofore accustomed," that would not have answered the purpose, because there has been no uniform custom about it. If therefore the Convention had interfered, it must have been by entering into a detail highly unsuitable to a fundamental constitution of government; if they had pleased some States they must have displeased others by innovating upon the modes of administering justice perhaps endeared to them by habit, and agreeable to their settled conviction of propriety. As this was the case it appears to me it was infinitely better, rather than endanger everything by attempting too much, to leave this complicated business of detail to the regulation of the future Legislature, where it can be adjusted coolly and at ease, and upon full and exact information. 37

The same comments were echoed by James Wilson in his 1787 address to the citizens of Philadelphia. ${ }^{38}$

In fact, the issue seemed not to be why the right was omitted, but whether omission was the proper solution to the problem. Alexander Contee Hanson, writing under the pseudonym Aristides, wrote:

Is there not a great variety of cases in which this trial is taken away in each of the states? Are there not many more cases where it is denied in England? For the convention to ascertain in what cases it shall prevail, and in what others it may be expedient to prefer other modes was impracticable. ${ }^{39}$

Thomas Jefferson agreed on the problem:

362 THE BILL OF RIGHTS: A DOCUMENTARY HISTORY, supra note 7, at 988.

371 THE BILL OF RIGHTS: A DOCUMENTARY HISTORY, supra note 7, at 454-55.

$38 \mathrm{Id}$. at 529-30; see also id. at 550-51 (remarks of Hugh Williamson).

39 Id. at 542. 
[T] here has been no uniformity among the states as to the cases triable by jury, because some have been so incautious as to abandon this mode of trial. ... ${ }^{40}$

Conversely, however, Jefferson felt this was a compelling reason for the convention to address the issue:

It would have been much more just and wise to have concluded the other way that as most of the states had judiciously preserved this palladium, those who had wandered should be brought back to it, and to have established general right instead of general wrong. 41

In any event, while the idea of civil trial by jury was considered before the Constitution went to the states for ratification, albeit briefly, it was left out of the final document. 42

\section{The Addition of the Seventh Amendment to the Constitution Did Not Further Define When Civil Juries Were Appropriate}

As touched upon above, the ultimate omission of a civil jury guarantee from the draft Constitution became a matter of central debate in the states, and the keystone of opposition to the Constitution. From France, Thomas Jefferson wrote to a friend that the Constitution "should have" protected the right. ${ }^{43}$ Similar sentiment resounded in the states. That opposition would ultimately lead to the Seventh Amendment. Yet, even the protracted debates in the states did not generate any consensus, or even much discussion, of when civil juries should be allowed.

Mr. Henderson summarizes the mood of the states: "It appears . . . that a general guarantee of the civil jury as an institution was widely desired, but that there was no consensus on the precise extent of its power. On the contrary, no one discussed the question in any detail." 44 The state debates thus reflect an inattention to when a jury would be appropriate. ${ }^{45}$

The states offered no workable rule defining civil jury rights beyond the basic concept that juries were a good idea. ${ }^{46}$ The best they could suggest was

4012 THE PAPERS OF THOMAS JEFFERSON, supra note 12 , at 440.

41 Id.

42 Henderson, supra note 5, at 292.

43 14 THE PAPERS OF THOMAS JEFFERSON, supra note 12, at 678.

44 Henderson, supra note 5, at 299.

45 Wolfram, supra note 5 , at $663,665-66$.

46 See Wolfram, supra note 5, at 663-66. 
that the Constitution should have some sort of recognition of the general principle of civil jury rights. ${ }^{47}$

Ironically, the states' position was precisely the sort of recital that the Federal Convention had rejected. When the "nearly final draft" of the Constitution came out of Committee, it did propose to protect jury rights in civil trials. It contained a clause that "trial by jury shall be preserved as usual in civil cases." 48 This language sheds some light on how the drafters proposed to solve their drafting problem. They would opt for vague language ("as usual") that would have the effect of confirming the importance of civil jury rights, but let each state protect those rights as it always had before. There is no record of the debate that led the drafters to this solution. All we know is that ultimately even this mild language was omitted. What is notable is that the states fared no better. As Mr. Henderson reports the state ratification debates, "Even their arguments ... . dealt with nothing more specific than the general proposition that civil juries were a good thing. $" 49$

The price the Anti-Federalists extracted for nine states to approve the Constitution was that the first Congress would pass a declaration of individual rights as amendments to the Constitution. ${ }^{50}$ Of the seven states that proposed amendments, six proposed language protecting civil jury rights. ${ }^{51}$ The proposed amendments evolved, of course, into the Bill of Rights. ${ }^{52}$ The Federalists committed to pass these amendments in the First Congress to avoid convening a second constitutional convention. ${ }^{53}$

It is remarkable, but apparently undisputed, that the records regarding the drafting and passing of the Bill of Rights add virtually nothing to an understanding of the language of the resulting Seventh Amendment. ${ }^{54}$ While the outcry for a civil jury right was a central part of the political negotiations that forced the creation of the Bill of Rights, the implementation of that guarantee carried no more definition than did the debate in the state houses. ${ }^{55}$

47 Id. at 663. While Mr. Wolfram debates whether the Anti-Federalists had more specific policy arguments than simply a general approval of juries (he believes they did), he does not suggest that they had a more specific idea of how to demarcate the scope of civil jury rights. Id. at 670-73; see also Henderson, supra note 5, at 299.

482 THE RECORDS OF THE FEDERAL CONVENTION OF 1787, supra note 23, at 628.

49 Henderson, supra note 5, at 292. Yet, it was this concern, of course, that led directly to the passage of the Bill of Rights. Id. at 289.

50 Wolfram, supra note 5 , at 725 .

51 DOCUMENTS ILLUSTRATIVE OF THE Formation OF THE UNION OF THE AMERICAN STATES, House DOC. No. 398, 69th Cong., 1st Sess. 1019 (Massachusetts), 1026 (New Hampshire), 1029 (Virginia), 1036 (New York), 1046 (North Carolina), 1054 (Rhode Island).

52 Wolfram, supra note 5 , at 725.

$53 \mathrm{Id}$.

54 Id. at 725-26.

55 Id. at 726. 
James Madison was the first to introduce draft language of a Bill of Rights. ${ }^{56}$ One of his proposed provisions was the clear predecessor language to the eventual final language of the Seventh Amendment: "In suits at common law, between man and man, the trial by jury, as one of the best securities to the rights of the people, ought to remain inviolate." 57 Madison's proposed language gives an interesting view of the type of suits that he considered appropriate for jury rights ("between man and man"). Nevertheless, the implications of that language are only meaningful for their omission from the final ratified version.

Madison's draft language appears to have been an amalgam of language proposed by various states. The language most closely resembles the Massachusetts proposal for a civil jury amendment to the Constitution that read, "In civil actions between citizens of different States, every issue of fact, arising in actions at common law, may be tried by a jury if the parties, or either of them, request it." 58 It also appears to draw on the Pennsylvania suggestion "That in controversies respecting property and in suits between man and man, trial by jury shall remain as heretofore, as well in the federal courts, as in those of the several states." 59 By contrast, Madison apparently did not rely on any part of the Maryland proposal guaranteeing juries in actions on debts, contracts, or for trespass. ${ }^{60} \mathrm{He}$ may, however, have relied in part on language that both North Carolina and Virginia suggested: "That, in controversies respecting property, and in suits between man and man, the ancient trial by jury is one of the greatest securities to the rights of the people, and to remain sacred and inviolable." 61

The key language in Madison's proposal is "In suits at common law." Even before the First Congress, Alexander Hamilton recognized the problem with language that defined jury trials by reference to "common law." Because of the widely divergent definitions among the states as to what was a suit at common law, it would be difficult to find a phrase with less clarity and meaning to define those cases entitled to a trial by jury. ${ }^{62}$

56 Id. at 726-27. Although Madison, as the author of the original Constitution, was accused of opposing a bill of rights, he protested this characterization and claimed he supported amendments such as one protecting civil jury rights. 1 THE BILL OF RIGHTS: A DOCUMENTARY HISTORY, supra note 7, at 996-97.

57 Wolfram, supra note 5 , at 727-28.

58 THE FEDERALIST, supra note 15, at 528; see also 2 THE BILL OF RIGHTS: A DOCUMENTARY HISTORY, supra note 7, at 677. New Hampshire proposed identical language. 2 ELLIOT'S DEBATES, supra note 11, at 203-04.

59 J.B. MCMASTER \& F.D. STONE, PENNSYLVANIA AND THE FEDERAL CONSTITUTION 421 (1888).

602 ELLIOT'S DEBATES, supra note 11 , at 547-56.

613 ELLIOT's DEBATES, supra note 11, at 658; 4 ELLIOT's DEBATES, supra note 11, at $243-44$.

62 THE FEDERALIST, supra note 15 , at 529-30. 
Hamilton's criticism was echoed in the First Congress. Federalist Samuel Livermore, former Chief Justice of New Hampshire, strongly opposed the Madison draft Bill of Rights, and in particular the jury trial language. ${ }^{63} \mathrm{He}$ enunciated the rather basic concern that not every case was best decided by a jury ${ }^{64}$ Implicit in this opposition is that he understood Madison's language as guaranteeing a jury right in every civil case; i.e., the predicate "In suits at common law," did not limit the set of civil jury rights in any manner whatsoever.

There is no record of what discussion, if any, Livermore's comments engendered; the next recorded event was that all of Madison's proposals for a bill or rights were referred out to a committee made up of a delegate from each of the eleven states that had thus far ratified the Constitution. ${ }^{65}$ The record of the discussion in that House committee reflects extensive comment on many of Madison's proposals on other issues. ${ }^{66}$ Amazingly, however, adoption of the proposed Seventh Amendment proceeded without controversy or remark. ${ }^{67}$ Thus, the Seventh Amendment was reported out of committee, without comment, in what is nearly its current form. The Senate (also without recorded discussion) subsequently added the language "where the consideration exceeds twenty dollars." 68

There is no record of any discussion in the states before ratification. ${ }^{69}$ The final language, as adopted, becanie:

In Suits at common law, where the value in controversy shall exceed twenty dollars, the right of trial by jury shall be preserved, and no fact tried by a jury, shall be otherwise reexamined in any Court of the United States, than according to the rules of common law. ${ }^{70}$

Placed in the context of its history, this language is, at best, ambiguous. There was no single set of "suits at common law" in 1791. There were at least thirteen. ${ }^{71}$ Thus, without further detail, the language "in suits at common law"

63 Wolfram, supra note 5, at 727-28.

64 Id. at 729 .

$65 \mathrm{Id}$. at 728 .

66 See 2 THE BILL OF RIGHTS: A DOCUMENTARY HISTORY, supra note 7, at 10501120.

67 Id.

${ }^{68}$ Wolfram, supra note 5, at 728-29; see also 2 THE BILL OF RIGHTS: A DOCUMENTARY HISTORY, supra note 7, at 1143-47.

69 Wolfram, supra note 5 , at 730 .

70 U.S. CONST. amend. VII.

71 Indeed, in 1791 Vermont became the fourteenth state, and so there may have been, by that time, yet another common law system. THE NEW YORK PUBLIC LIBRARY DESK REFERENCE 693 (1989). 
could not imply any black-letter rule at all, because it could give no direction as to which cases, which issues, or which procedures were ripe for juries.

Madison, the ultimate author of the Seventh Amendment, must have known that. It was a central issue raised by one of his co-authors to the Federalist Papers. Further, when he proposed his language to the First Congress, the criticism of his language was that it did not define when jury trials were permissible. Yet, Madison obviously was comfortable allowing this ambiguity. He declined the opportunity to choose among the thirteen states' definitions of common law.

The First Congress also chose not to give more precise definition to "common law." Thus, the language never acquired explicit meaning. The most it could mean is that each state had its own class of common law cases, and within each state that class of cases carried a jury right; thus jury rights should continue in those sorts of cases. ${ }^{72}$

When the Supreme Court later looked back on the language of the Seventh Amendment, the Court interpreted the purpose of the Amendment as intended "to preserve the right to jury trial as it existed in 1791." characterization, perhaps inadvertently, highlights the interpretation problem with the Seventh Amendment. The drafters wished to preserve jury trial rights as they existed, but because there was such divergence of those rights there was no single rule by which they could do so. Accordingly, they were reduced to drafting an amendment that, read in context, said no more than "jury trials are a good idea and we should have them in the same manner as we have always had them." Yet, because there was no single manner in which the drafters had always had jury trials, the Amendment's language was essentially nothing more than an affirmation of a principle, not the laying down of a defined rule. ${ }^{74}$

\section{THE EVOLUTION OF THE SEVENTH AMENDMENT IN THE COURTS}

One might have expected that the courts, faced with interpreting the precatory language of the Seventh Amendment, would have addressed the issue and devised a body of common law independent of the Seventh Amendment to define the scope of civil jury rights in federal court and thus effectuate the principle of the Seventh Amendment. That did not happen.

The first case interpreting the Seventh Amendment arose less than twenty years after the passage of the Bill of Rights. It was United States v. Wonson,

72 One might even speculate that this was a direction that a federal court give the same jury right as did its forum state-a kind of hybrid between "jury trial as usual in civil cases" and Erie v. Tompkins, 304 U.S. 64 (1938).

73 Curtis v. Loether, 415 U.S. 189 (1974).

74 But see Shapiro and Coquillette, supra note 3, at 454 (the history of the Seventh Amendment cannot support an analysis of intent). 
decided by Mr. Justice Story on circuit in 1812.75 Samuel Wonson had successfully defended a claim by the United States that he owed penalties under the Embargo Supplementary Act of 1808. The government appealed, and Justice Story was asked to decide "whether the facts are again to be submitted to a jury in this court, or the appeal submits questions of law only for the consideration of the court."76 $\mathrm{He}$ found that the legislation creating appellate jurisdiction rejected the notion of a second jury.

Justice Story then turned to the constitutional clauses regarding appeals. He reasoned that the Seventh Amendment was specifically crafted to restrict the higher courts from nullifying jury verdicts of the lower courts. ${ }^{77}$ But then Justice Story made the historic leap of faith-he assumed that the Seventh Amendment must set forth a black-letter rule of law defining when juries were appropriate.

How did Justice Story justify his assumption? The language "in suits at common law" does not in and of itself mandate that assumption, and in fact the history of the language actually suggests the contrary. He recognized, however, "how deeply the subject [civil jury rights] at that time [the drafting of the amendment] interested the several states," and concluded that this gave insight into the "scope and object of the amendment . . . ."78 In other words, Justice Story recognized that the Americans of the time felt civil jury rights were of paramount importance, and that the Seventh Amendment reflected that view, so he concluded that the amendment must define those rights. If this were reduced to a syllogism, it would be:

Step 1: The founding fathers felt civil jury rights were of paramount importance.

Step 2: The Seventh Amendment memorializes some version of these views.

Step 3: Therefore, the Seventh Amendment guarantees civil jury rights in certain defined cases.

Once Justice Story concluded that the Seventh Amendment provided a guarantee, he had a secondary problem. If the amendment provided a guarantee, what was it? Given the language of the amendment, if such a guarantee was to be found, then as a matter of grammar and syntax, that rule could only be embodied in the reference to "common law." But Federalist

7528 F. Cas. 745 (C.C.D. Mass. 1812) (No. 16,750).

76 Id. at 745 . Story recounts how at least some states did have the practice of second juries on appeal. Id. at 748 .

${ }^{77} \mathrm{He}$ supported this conclusion by relying on Hamilton's Federalist Paper No. 83. Id. at 750 .

${ }^{78} \mathrm{Id}$. 
Paper No. 83, with which Justice Story was familiar, ${ }^{79}$ made clear that if "common law" was read as a reference to American practice, then it provided no rule at all. Each of the thirteen states had its own corpus of common law rules. Thus, Justice Story was forced to conclude that "common law" was a reference to England, which arguably was the only other even theoretically available solution:

Beyond all question, the common law here alluded to is not the common law of any individual state (for it probably differs in all), but it is the common law of England, the great reservoir of all our jurisprudence. It cannot be necessary for me to expound the grounds of this opinion, because they must be obvious to every person acquainted with the history of the law. 80

If Justice Story had tried to explain the basis for his assertion that "common law" referred to England, he would have found the task nearly impossible. There is no recorded legislative history suggesting that the phrase "common law" referred to the common law of England. Nor is support found in the records of the state debates, the Federalist Papers, or the writings of commentators of the time. ${ }^{81}$ His assertion had no documentable basis. ${ }^{82}$

The reason Justice Story came to an unsupportable conclusion, of course, is that he began with a faulty syllogism. The Seventh Amendment did not contain a black-letter rule of law. In fact, it intentionally omitted one. But once Justice Story assumed the contrary, he had no choice but to find it within the language "common law."

Justice Story's assertion that his reasoning is so obvious that it "cannot be necessary for [him] to expound" is an unfortunate turn in legal history. This is especially so because in the aftermath of Wonson, no later court has revisited Wonson's holding. As Mr. Wolfram notes about Justice Story's decision, "No federal case decided after Wonson seems to have challenged this sweeping proclamation; perhaps later judges have hesitated to appear to be the kind of intractable person that would require Mr. Justice Story to elaborate on the obvious." ${ }^{83}$ Thus, because Justice Story's conclusion went unchallenged, his unexplained and faulty holding became the central thread in the fabric of our jury practice.

79 He cited Federalist Paper No. 83 within his opinion. Id.

${ }^{80} \mathrm{Id}$.

81 Indeed, Hamilton's concerns seem to suggest the opposite. See THE FEDERALIST, supra note 15 , at $516-32$.

82 While this Article quotes or cites to most surviving documents of the time, not one of the documents suggest that what Justice Story says is "obvious." E.g., Shapiro \& Coquillette, supra note 3 , at 448-49.

83 Wolfram, supra note 5 , at 641 . This observation is a haunting echo of the quoted childrens' story that begins this Article. 
When an entire body of law flows from an inaccurate syllogism, trouble inevitably looms. The application of Wonson as law of the land led to a series of difficult questions and seemingly inexplicable results. Application of Wonson's principles was an unwieldy task at best, and has become increasingly strained with the passage of time.

The Wonson interpretation of the Seventh Amendment became known as the "historical test." 84 Under the historical test, in order to determine whether a civil case carries a jury right, one must hypothetically place the case in England and ask if it would have had a jury right there. By 1898, the Supreme Court had expressly recognized that the Sixth and Seventh Amendments' phrase "trial by jury" not only meant that a case should be compared to English practice, but also that the comparison was fixed in time to English practice in $1791 .{ }^{85}$ As Mr. Wolfram notes, this holding was probably of no great moment since it was still many years before the law in federal courts began to substantially diverge from eighteenth century English practice. ${ }^{86}$ Certainly the courts did not perceive themselves as eroding jury rights. Rather, the Seventh Amendment continued to be called "fundamental and sacred."87 Yet, the irony in the situation and the problem was still inevitable-so long as jury rights were defined by the historical test, they could not be more sensibly predicated on an analysis of the principles sought to be achieved by providing a right to a jury, or on the limitations inherent in a jury trial. ${ }^{88}$

Anomalies eventually did surface. Over time the historical test-derived to give force to the attempt to preserve traditional jury rights-ironically became the driving force for the erosion of jury rights. With the passage of time, federal practice did quite substantially evolve. In particular, it seems that as the twentieth century progressed, the pace of change quickened. Thus, for

84 See, e.g., id. at 639.

85 Thompson v. Utah, 170 U.S. 343, 350 (1898); see also Dimick v. Schiedt, 293 U.S. 474 (1934).

86 Wolfram, supra note 5, at 642. Indeed, in federal courts "two distinct procedures, one at law, the other in equity, continued until 1912 when a blending set in." MOORE ET AL., supra note 4, 938.03 .

87 Jacob v. New York, 315 U.S. 752 (1942); see also Simler v. Conner, 372 U.S. 221, 222 (1963) ("The federal policy favoring jury trials is of historic and continuing strength."); Baylis v. Travelers' Ins. Co., 113 U.S. 316, 321 (1885) ("This constitutional right this court has always guarded with jealousy."); accord Chauffeurs, Teamsters and Helpers, Local No. 391 v. Terry, 494 U.S. 558, 563-66 (1990).

88 One might ask, what is so wrong about looking to English law as a point of reference. The answer is that to do so simply creates new problems. English jury rights evolved out of the Magna Carta, the anomalous dual court systems of law and equity, and the peculiar evolution of the English jury system. In other words, they evolved in part as a result of an idiosyncratic history. By contrast, with the benefit of hindsight and the ability to write on a clean slate, there is no logic in maintaining the characteristics of a system that are historically explainable but not philosophically preferable. 
example, as one writer noted in 1984, "Modern securities and antitrust cases ... can involve an enormous number of parties and claims, highly technical factual inquiries, tremendous volumes of documentary evidence, and trials lasting several years." 89 That sort of litigation would quite obviously have been completely foreign to the courts of King George.

Because of the evolution of federal practice (both substantively and procedurally), the application of the historical test led to the creation of a growing class of cases which were exempted from the Seventh Amendment on an ad hoc, patchwork basis. For example, bankruptcy trials do not fall within the amendment. ${ }^{90}$ Thus, the same case may or may not have a jury purely because of the solvency of the defendant. ${ }^{91}$ Likewise, jury trials attach to patent cases seeking money damages, ${ }^{92}$ but not to cases involving injunctive relief. ${ }^{93}$ Why is a jury appropriate for one and not the other? Similarly, one might ask why there is no jury right in eminent domain actions. ${ }^{94}$

If we were working from a clean slate, our definition of jury rights would be based on an analysis of the policies and principles we believe we effectuate through the jury system, and of the cases which best serve these purposes. The patchwork solution that has evolved does not derive from any such policy analysis, but rather from the historical test. There is no doubt that juries are presently excluded from cases that as a matter of policy they should hear, and conversely, that juries hear cases in which they should not be involved. Despite these anomalous results, every year the analysis continues based upon the historical test. Every year, we look back to England in 1791, and every year that analysis looks back from a perspective that is more and more unlike anything old England had ever seen. Thus, each year the class of cases considered to fall outside of the guarantee of the Seventh Amendment continues to expand, but for no articulable reason. ${ }^{95}$

Two cases, in particular, highlight the sort of unnecessary mental gymnastics that have resulted from the courts' failure to question the historical test. The first is Galloway v. United States..$^{96} \mathrm{Mr}$. Galloway sought benefits for total and permanent disability under an insurance contract issued by the United

89 Douglas King, Complex Civil Litigation and the Seventh Amendment Right to a Jury Trial, 51 U. CHI. L. REV. 581, 581-82 (1984).

90 Katchen v. Landy, 382 U.S. 323, 336-37 (1966).

91 Or even more inexplicably, on a judge's decision whether to grant relief from the automatic stay instead of handling the dispute as an adversary proceeding in bankruptcy.

92 Bereslavsky v. Caffey, 161 F.2d 499 (2d Cir.), cert. denied, 332 U.S. 770 (1947).

93 Protexol Corp. v. Koppers Co., 12 F.R.D. 7 (S.D.N.Y. 1951); National Dryer Mfg. Corp. v. Dryer Co. of Am., 130 F. Supp. 912 (E.D. Pa. 1955).

94 United States v. Reynolds, 397 U.S. 14 (1970).

95 In order to justify this evolution, the Supreme Court held that "the Amendment did not bind the federal courts to the exact procedural incidents or details of jury trial according to the common law in 1791 . . . " Galloway v. United States, 319 U.S. 372, 390 (1943).

96 Id. at 372. 
States pursuant to the War Risk Insurance Act. He claimed that his permanent disability (insanity) occurred during his service in the U.S. military. The trial court entered a directed verdict against Mr. Galloway, and one of the central questions he raised on appeal was whether directed verdicts deprive a party of the right to a jury trial.

The Supreme Court rejected the argument that procedural mechanisms to keep a case from the jury infringed on the Seventh Amendment. First, the Court applied the historical test and concluded that suits to enforce monetary claims against the sovereign could not be maintained under the common law in 1791, and therefore did not fit within the range of the Seventh Amendment. ${ }^{97}$ Second, the Court held that the procedural evolution of the legal system (Galloway was decided just a few years after the adoption of the Federal Rules of Civil Procedure), while potentially eroding the scope of cases that would go to a jury, did not offend the Seventh Amendment. Rather, "the Amendment did not bind the federal courts to the exact procedural incidents or details of jury trial according to the common law in 1791, anymore than it tied them to the common-law system of pleading or the specific rules of evidence then prevailing." 98

In fact, the Galloway Court rejected the strict application of the historical test to procedural questions because "the passage of time has obscured much of the procedure which then may have had more or less definite form, even for historical purposes." 99 Thus, the Court concluded that the Seventh Amendment "was designed to preserve the basic institution of jury trial in only its most fundamental elements, not the great mass of procedural forms and details, varying even then so widely among common-law jurisdictions." 100

The Galloway majority's analysis faced an aggressive dissent written by Justice Black, and joined by Justice Douglas and Justice Murphy. The dissent began with the premise that while "the founders of our government thought that trial of fact by juries rather than by judges was an essential bulwark of civil liberty ... [t] doday's decision marks a continuation of the gradual process of judicial erosion which in one hundred fifty years has slowly worn away a major portion of the essential guarantee of the Seventh Amendment."101 The dissent then reviewed the history of the Amendment, and the almost unanimous historic view that juries were a critical link in the legal system. The dissent traced how a series of procedural reforms were allowing judges, instead of juries, to make determinations of fact, which the dissent concluded was a history of "the constriction of a Constitutional civil right and should not be

\footnotetext{
97 Id. at 388-89.

$98 \mathrm{Id}$. at 390.

$99 \mathrm{Id}$. at 392.

100 Id.

101 Id. at 397.
} 
continued."102 The dissent concluded, "the call for the true application of the Seventh Amendment is not to words, but to the spirit of honest desire to see that Constitutional right preserved. Either the judge or the jury must decide facts and to the extent that we take this responsibility, we lessen the jury function." 103

The disagreement between the majority and the dissent in Galloway brought to the fore the problems that flowed from relying on the historical test and its faulty premise. Both the majority and dissent recognized the fundamental importance the founders placed upon civil jury rights. Both recognized that the Seventh Amendment memorialized the founders' principles. Both accepted the Wonson interpretation as the governing rule. Finally, ignoring that the Wonson interpretation made sense only within the context of the early 1800 's, they were forced to try to explain a result that with the passage of time had lost whatever logic it might once have had.

As Galloway perhaps foreshadowed, newly enacted Federal Rule of Civil Procedure 38 became the latest vehicle to speed the erosion of civil jury rights. Rule 38 provides in pertinent part:

The right of trial by jury as declared by the Seventh Amendment to the Constitution or as given by a statute of the United States shall be preserved to the parties inviolate. 104

Rule 38 replaced 28 U.S.C. section 770 (1940), which read in pertinent part:

The trial of issues of fact in the district courts, in all causes except cases in equity and cases of admiralty and maritime jurisdiction, and except as otherwise provided in proceeding in bankruptcy, shall be by jury. ${ }^{105}$

As Professor Moore tells us, "[t]he substance of this provision appeared in the first Judiciary Act of 1789 to safeguard the right of jury trial, largely because the Seventh Amendment had not yet been adopted."106 The statutes, by their literal terms, however, were potentially broader than the amendment because the approach of the statute was to define the set of nonjury cases, with the rest of the universe of cases having a jury right. Since the amendment took the opposite course, if an unanticipated set of cases arose, such as newly created statutory causes of action, section 770 appended jury rights while the amendment might not. Rule 38 merely codified the amendment, thus insofar as

102 Id. at 405.

${ }^{103}$ Id. at 407 .

${ }^{104}$ FED. R. CIV. P. 38.

10528 U.S.C. \$ 770 (repealed 1934).

106 MOORE ET AL., supra note 4, \38.07[2]. The passage of the first Judiciary Act of 1789 did not obviate the need for the amendment because "what Congress had given it could modify or take away." Id. \38.08[5.-1]. 
section 770 gave rights broader than the amendment, Rule 38 eroded those rights. ${ }^{107}$

The Supreme Court reinforced the erosion foreshadowed in Galloway thirty years later in Parklane Hosiery Co. v. Shore. ${ }^{108}$ Parklane was a stockholder's class action brought against a corporation and certain of its officers, directors, and stockholders, alleging violations of the Securities Exchange Act of 1934. Before the action came to trial, the SEC issued an injunction against the same defendants with regard to the same conduct. The plaintiff in the stockholders' action then moved for partial summary judgment asserting that the defendants were collaterally estopped from relitigating the issues that had been resolved against them in the SEC action. The district court denied the motion on the ground that such an application of collateral estoppel would violate the Seventh Amendment. The United States Court of Appeals for the Second Circuit reversed, and the United States Supreme Court affirmed.

As in Galloway, the majority of the Court rejected a rigid application of the Seventh Amendment. The petitioners in Parklane argued that since the common law in 1791 only permitted collateral estoppel where there was mutuality of parties, collateral estoppel could not be constitutionally applied when such mutuality was absent. The Court based its rejection of this argument on Galloway's holding that the Seventh Amendment only spoke to the fundamental elements of the basic institution of jury trials, not to the details of procedure or evidence. ${ }^{109}$

Then Associate Justice Rehnquist was the sole dissenting voice in Parklane. Referring to Justice Black's dissent in Galloway, Justice Rehnquist suggested that "regrettably, the erosive process continues apace with today's decision." 110 Justice Rehnquist's analysis closely paralleled that of Justice Black. He reviewed the history of the amendment and concluded that preservation of the jury right required application of historical standards so that the right which existed under the English common law when the amendment was adopted continued to be preserved. ${ }^{111}$ While Justice Rehnquist recognized that a rigid preservation of jury rights would not necessarily lead to a more efficient judicial system, he nonetheless read the Constitution as requiring passionate protection of defined jury rights. ${ }^{112}$ Implicit in his analysis was continued recognition of the Seventh Amendment as a black-letter rule of law.

Once the majority in Parklane recognized that the Seventh Amendment only spoke to the basic institution of jury trials, not the details, why did it decline to offer a meaningful rule for supplying those details? If the Court had

107 Id. at \{ 38.07[2].

108439 U.S. 322 (1979).

$109 \mathrm{Id}$. at 335-37.

$110 \mathrm{Id}$. at 339 .

$111 \mathrm{Id}$. at 344 .

$112 \mathrm{Id}$. at 346-50. 
recognized that the Seventh Amendment did not, in fact, guarantee a jury trial in any particular instance, or even give a guideline for deciding when jury trials were appropriate, then the Court could have explored ways to fill this void. But, that would require re-examining the analysis of Justice Story. Because the Court did not question the propriety of Story's analysis, the Court was forced to adopt the awkward and almost oxymoronic result that the historical test (a test that by definition was fixed in time) could be adapted with the passage of time. Since that conclusion was drawn from a faulty premise, it carried the logical cracks that Justice Rehnquist's dissent exposed.

Justice Rehnquist's dissent, however, offered no improvement. While the dissent recognized the inconsistencies of the majority's analysis, it made no meaningful attempt to identify the cause of those inconsistencies. Justice Rehnquist ultimately offered no more direction than the general suggestion that jury rights should not be constricted. He offered no philosophical framework for determining the scope of when jury rights should arise. He rather reiterated the Wonson test in defining rights simply by taking a snapshot of a moment in time. Thus, both Parklane and Galloway highlight a tension in jurisprudence that results from the flawed premise that the Seventh Amendment fixed the jury rights to a particular class of cases, and precluded further evolution of the right.

By precluding evolution, the historical test undercuts the fundamental nature of the amendment. The Seventh Amendment, by its language, provides a floor-a minimum of situations in which jury rights exist. ${ }^{113}$ The amendment neither guarantees any set of rights to a nonjury trial nor prohibits an expansion of jury rights beyond those the amendment protects. ${ }^{114}$ Some commentators suggest that the courts have reacted by applying a bias, in close questions, to empaneling a jury. ${ }^{115}$ A solid argument exists that this bias is precisely what the drafters of the amendment intended. Yet, as Justices Black and Rehnquist explain, that apparent bias is largely an illusion-lip service recognition of the importance of civil jury rights has done little to check the erosion of those rights. Further, this debate glosses over the underlying question, which is how the amendment defines the floor.

Over time, the application of the historical test became more and more surreal. Asking how 1791 England would deal with a 1991 multi-district patent infringement case is a little like asking how the War of the Roses would have turned out if both sides had airplanes. Not until 1970 did the Supreme Court

113 Kane, supra note 3, at 4 \& n. 10.

114 Id. Interestingly, while Congress can expand jury rights, it is more difficult for Congress to contract them. The mere fact that Congress enacts a statute preserving or creating a cause of action does not mean that there is no jury right. If the action historically would have required a jury, then under the historical test it still carries a jury right unless Congress explicitly documents why a jury trial is an inadequate procedure. Id. at 12-27.

115 Shapiro \& Coquillette, supra note 3 , at 442. 
reflect serious doubt on the historical test. That doubt arose in Ross $v$. Bernhard. ${ }^{116}$ There, the Court suggested in a passing comment in a footnote that the right to a jury in a particular case might turn, at least in part, on the "practical abilities and limitations of juries." 117 Since that footnote, however, the Court has not wavered significantly further from the historical test enunciated in Wonson. ${ }^{118}$

In the 1980's, more anomalies flowed from the reliance on the historical test. In the wake of Ross, some litigants started arguing for a complexity exception to the right to a jury trial. These arguments were grounded in due process and an innovative application of Wonson's historical test. Then, in 1976, a district judge in the state of Washington relied on the Ross $v$. Bernhard footnote to strike a jury demand in a complex securities case. ${ }^{119}$ This opened the floodgates on a discussion of whether a complexity exception existed to the Seventh Amendment.

The literature addressing the complexity exception was intense. ${ }^{120}$ The courts failed to reach a consensus outcome (and still are split whether to recognize the exception). ${ }^{121}$ Nevertheless, in spite of this renewed thinking on the subject, no court undertook a re-examination of Wonson-thus the heart of the debate continued to be a focus on the practices of eighteenth century England.

Once again, this led to phenomenal mental gymnastics. An illustration can be found in the publication in 1984 of an article by Douglas King in the University of Chicago Law Review. ${ }^{122}$ Mr. King's initial premise was both simple and compelling. He recognized that, "[t]he last fifty years have seen a

116396 U.S. 531 (1970).

$117 \mathrm{Id}$. at $538 \mathrm{n} .10$.

118 See Wolfram, supra note 5, at 648-49; see also Tull v. United States, 481 U.S. 412, $418 \mathrm{n} .4$ (1987) ("The Court has also considered the practical limitations of a jury . . . . But the Court has not used these considerations as an independent basis for extending the right to a jury trial under the Seventh Amendment.") In two cases, however, the Court has suggested that it could waiver from strict adherence to the historical test to expand jury rights. See Beacon Theatres, Inc. v. Westover, 359 U.S. 500 (1959); Dairy Queen, Inc. v. Wood, 369 U.S. 469 (1962).

119 In re Boise Cascade Securities Litigation, 420 F. Supp. 99 (W.D. Wash. 1976).

120 See, e.g., Morris S. Arnold, A Historical Inquiry Into the Right to Trial by Jury in Complex Civil Litigation, 128 U. PA. L. REV. 829 (1980); Morris S. Arnold, A Modest Replication To a Lengthy Discourse, 128 U. PA. L. REV. 986 (1980); James S. Campbell \& Nicholas Le Poidevin, Complex Cases and Jury Trials: A Reply to Professor Arnold, $128 \mathrm{U}$. PA. L. REv. 965 (1980); Patrick Devlin, Jury Trial of Complex Cases: English Practice at the Time of the Seventh Amendment, 80 COLUM. L. REV. 43 (1980).

121 See, e.g., Zenith Radio Corp. v. Matsushita Elec. Indus. Co., 478 F. Supp. 889 (E.D. Pa. 1979), vacated, 631 F.2d 1069 (3d Cir. 1980); In re United States Fin. Sec. Litig., 75 F.R.D. 702 (S.D. Cal. 1977), rev'd, 609 F.2d 411 (9th Cir. 1979), cert. denied, 446 U.S. 929 (1980).

122 King, supra note 88. 
tremendous liberalization of civil procedure and an unprecedented proliferation of new causes of action, which together make it possible for civil litigation to reach a level of complexity exceeding anything imaginable in the common law courts of 1791."123 Therefore, "[t]he search for a complex-case exception to the Seventh Amendment that has engaged some authors is ... misguided, because 'complex' cases did not and could not occur in the common law system to which the framers were accustomed." 124

Mr. King's thesis then was to change the focus of the debate. He suggested that the proper analysis was not on the type of case, a focus that passage of time had made obsolete. Rather, Mr. King urged that the proper focus was on procedure. ${ }^{125} \mathrm{He}$ presented a statistical analysis of literally every civil case reported in England during the years 1789 to 1791, and found that only the very simplest of cases were tried to a jury in eighteenth century England. ${ }^{126}$ As a matter of common law procedure, a complex case simply could not arise in the common law courts. ${ }^{127}$ Thus, concluded Mr. King, there should be a complexity exception to the Seventh Amendment. ${ }^{128}$

Mr. King had to go to great lengths to fashion a rule because he, like previous commentators, assumed that a jury right "in suits at common law" was a black-letter rule of law. Thus, he had to redefine the content of the rule. ${ }^{129} \mathrm{He}$ could not offer any evidence that the language of the Seventh Amendment, either by history or evolution, was intended to focus on the procedural availability of the common law courts to complex cases. The debate surrounding the Seventh Amendment never addressed that issue. To the contrary, the language of the Seventh Amendment was chosen precisely to avoid any preference among the divergent procedural rules of the thirteen states. Yet, Mr. King had to make his historically insupportable argument because he never questioned Justice Story's assumption.

123 Id. at 581.

$124 \mathrm{Id}$. at 608 .

$125 \mathrm{Id}$. at 584 .

$126 \mathrm{Id}$. at $590-608$.

$127 \mathrm{Id}$. at 608 .

$128 \mathrm{Id}$. at 609-14. One of the fascinating aspects of Mr. King's work is that he does not seem to realize how much his proof demonstrates. If his analysis is accepted, then it not only allows for a complexity exception, but also allows for an exception in all but the very simplest of cases. Since increasingly the simplest of cases never find their way into a federal court, and if they do then they are quickly referred to a magistrate, in essence Mr. King's analysis would allow for an exception to the Seventh Amendment in virtually every case.

129 Q: How many lawyers does it take to screw in a light bulb?

A: It depends on how you define "light bulb." 


\section{MOVING TOWARDS A MORE SENSIBLE INTERPRETATION OF THE SEVENTH AMENDMENT}

Debunking the myth of the historical test as a means of interpreting the Seventh Amendment resolves one set of problems by eliminating the constraints of an increasingly unworkable rule. Simultaneously, it presents the formidable task of identifying a new and better interpretation of the amendment. This requires attention not only to the language of the Seventh Amendment, but also to the goals of its drafters.

A pure focus on the language, without reference to its intent in historical context, is problematic. It is clear that the drafters of the Seventh Amendment struggled with the attempt to define a set of civil cases in which there was a guaranteed right to a jury trial. They appeared to find themselves either incapable or unwilling to delineate a clear rule. Instead, they chose language which did not explicitly embody any particular rule, but did reaffirm the high degree of importance they placed on civil jury rights. While that language may have been a reasonable compromise for the drafters, it left open a difficult interpretation issue for subsequent generations. As Justice Story's decision in Wonson demonstrates, interpretation of the amendment's language without regard to its historical context can easily lead to anomalous, and indeed discordant results. For example, although Justice Story ultimately concluded that "common law" referred to English practice, there is no evidence the drafters had anything of the sort in mind.

When confronted in practice with the Seventh Amendment, the courts first had to determine whether the Amendment contained an implicit black-letter rule of law, or its language was merely precatory. Taken out of historical context, the language supports both interpretations. The courts immediately opted for the position that the language was more than simply precatory. This presented the courts with the need to interpret the words "in suits at common law" to derive the substance of the supposed black-letter rule. Certainly jury trial rights were not guaranteed in all cases, because "in suits of common law" necessarily had to refer to some subset. Justice Story assumed that this subset consisted of the existing common law courts of England. By relying on this syllogism, Justice Story enunciated a rule which not only was foreign to the intent of the drafters, but was neither jurisprudentially nor philosophically related to the purposes and benefits of the jury system.

Perhaps the most troublesome aspect of Justice Story's decision is the manner in which he chose to phrase it. When the drafters declined to define specific cases to empanel juries, it became inevitable that the courts would have to fill in the detail. One might have expected a sort of socratic dialogue to follow, leading ultimately to the reconciliation of alternative and competing interpretations. This process was instead truncated by Justice Story's aggressive and dogmatic "discovery" of the "obvious" interpretation of the Seventh 
Amendment. Consider, for example, how differently our jury practice might have evolved if Justice Story had treated his decision as the opening salvo in an interesting discussion on constitutional interpretation, rather than the closing shot. Instead, he described his decision in such assertive language that it foreclosed further inquiry. ${ }^{130}$

It would be unfair to say that Justice Story's analysis had no legitimacy. Before Erie v. Tompkins, ${ }^{131}$ federal common law was a potential source of federal rights, and before there was a sizeable body of federal common law, a federal court might have been quite tempted to look to English precedent for guidance. Indeed, Justice Story decided Wonson when the judicial branch was only twenty years old, at a point when its legitimacy would undoubtedly have been more prudently grounded on a long historical tradition and pre-existing law, rather than on the creation of new policy divorced from established precedent. 132

With the passage of time, however, Justice Story's black-letter solution started to show cracks. It was inevitable that the complexity of modern civil litigation would expand those cracks into gaping fissures. The result is a rather piecemeal and anomalous set of rules that govern and define the cases which have jury trial rights. ${ }^{133}$ There is no coherent philosophical thread that can explain why a case should fall in one class or the other. The explanation is grounded solely in time, not in reference to the abilities of jurors or the purposes the drafters sought to achieve by guaranteeing jury trials. Indeed, because the English system of civil jury practice has continued to evolve, linking American jury rights to the status of English rights in 1791 is unjustifiably arbitrary and unreasoned. ${ }^{134}$

130 "Beyond all question . . . [i]t cannot be necessary for me to expound the grounds of this opinion, because they must be obvious . . . Un United States v. Wonson, 28 F. Cas. 745, 750 (C.C.D. Mass. 1812) (No. 16,750).

131304 U.S. 64 (1938). In fact, in the wake of Erie, one might argue that in diversity cases a federal court ought to apply the jury rules of its forum state.

132 Further, it is not crystal clear that the historical test applied today is the one Justice Story had in mind. His opinion was ambiguous in its reference to England, and could be interpreted as referring to the principles of English practice, not the logistical applications. It may be that later courts mistakenly assumed he meant the system itself.

133 See Damsky v. Zavatt, 289 F.2d. 46 (2d Cir. 1961) (the historical test "may seem to reek unduly of the study" and is a "strain upon history").

134 Indeed, early English practice was the opposite of present practice. The historical exclusion of juries from English courts is largely the result of an historical quirk; equity courts were only created because of the inability of common law courts to quickly develop new causes of action or types of relief. Note, The Right to a Nonjury Trial, 74 HARV. L. REV. 1176, 1179-82 (1961). Apparently, if common-law courts had been more flexible, there would have been less recourse to the courts of equity, and many more cases would have involved juries. Thus, picking a snapshot moment of English practice is, in the truest sense, arbitrary. 
If one rejects Justice Story's historical test as unworkable, then the analysis of the language of the Seventh Amendment returns to the starting point. First, one must recognize that the language of the amendment arguably is consistent both with the view that the amendment provides the broad construct of a blackletter rule, and with the view that the language is simply precatory.

It would be wrong, however, to read the amendment as precatory. The interpretation of the Seventh Amendment as a precatory plea would place a great amount of unchecked power in federal judges. Precatory language is, by definition, not binding. ${ }^{135}$ If the amendment is precatory, then the courts are free to define jury practice however they wish. That freedom presents both a seductive opportunity and a serious risk.

The opportunity is the unfettered ability to fashion a coherent, integrated system of jury practice based on the perceived goals of the jury system, and the capabilities and limitations of juries. This system could be used to define jury rights in a way that would improve our court system, promote our democratic beliefs, and lead to more just results. Better still, it would evolve and adapt if the passage of time changed circumstances.

The danger of reading the Seventh Amendment as precatory, however, is serious. That danger is that courts and legislatures could simply pay lip service to the importance of juries, while in practice juries might disappear except in the simplest of cases. If the language was read as precatory, such an erosion would be immoral, but not unconstitutional.

The reality of the danger of that erosion is readily apparent. In retrospect, later English history shows that the fears of the Anti-Federalists had some validity. In the 200 years since the adoption of the Seventh Amendment, while the United States has anguished over jury rights, England has virtually eliminated juries from civil cases. ${ }^{136}$ Much closer to home, as Justices Rehnquist and Black point out, jury rights continue to erode in contemporary American practice even in the face of the Seventh Amendment. These developments make clear the possibility that left without a constitutional restraint, a federal government might well eliminate jury practice. ${ }^{137}$

Rejection of a precatory interpretation of the amendment simply leads to a different dilemma, however. The language of the amendment does not describe a rule; rather, because of the widely divergent definitions among the states in 1789 as to what was a suit at common law, it would be difficult to find a phrase with less clarity and meaning to define those cases entitled to a trial by jury. How then, if the language is not simply precatory, does one interpret the amendment?

135 BRYAN A. GARNER, A DICTIONARY OF MODERN LEGAL USAGE 426 (1987).

136 Shapiro \& Coquillette, supra note 3 , at 443 n.4, 450.

137 Indeed, that is precisely what Shapiro and Coquillette advocate. Id. at 457-58. 
The answer lies in moving beyond the language, and reflecting again on the original intent of the drafters. In 1789, there was a shared perception that guaranteeing the right to civil jury trials was important. Without an impartial jury, the individual citizen had no ability to check the power of the sovereign in a civil courtroom. Legislators and presidents are elected. Federal judges serve for life.

Before there was a draft Constitution, each state actively promoted juries as a check on judges. Indeed, the states became active social laboratories which, in part, explored the extent to which juries could become productively integrated as an essential part of the checks and balances of the new federal system. For example, some states permitted juries to decide all questions of fact and all questions of law. ${ }^{138}$ Some even had a jury empaneled on appeal. ${ }^{139}$

The Seventh Amendment was a by-product of this social laboratory. The Anti-Federalists distrusted the Federalists' assurance that civil juries were inviolate. The amendment the Anti-Federalists demanded reflected their belief that absent explicit language to the contrary, juries could slowly disappear from the civil courtroom, leaving judges as courtroom kings. ${ }^{140}$ The principle captured in the amendment is that this specter of unchecked authority was unacceptable. ${ }^{141}$

Today, the phrase "common law" can be interpreted in a way that is both in harmony with the mood of 1789 (unlike the historical test) and does not ignore the plain meaning of the language itself (unlike King). In modern usage, "common law" refers to any of four contrasting principles: (1) common law as the counterpart to civil law, (2) common law as the counterpart to equity, (3) common law as the counterpart to ecclesiastical law, and (4) common law as the counterpart to statutory law. ${ }^{142}$ In the context of the American legal system the first and third definitions encompass all civil cases, yet the history of the amendment reflects that this was not its intent. Justice Story assumed that "common law" was a variant of the second definition. The history of the amendment will similarly not support this reading, however, because the language of the amendment provides no guidance as to which, if any, of the fourteen contemporary systems delineating common law from equity (thirteen states and England) is to be followed. But there is no similar problem in reading the language as a variant of the fourth definition. This latter definition refers to the concept of an evolving and adapting body of law developed by judges in response to changing societal demands. It distinguishes judge-made law from legislation.

138 Paul D. Carrington, The Seventh Amendment: Some Bicentennial Reflections, 1990

U. CHI. LEGAL F. 33, 44 (1990).

139 THE FEDERALIST, supra note 15 , at 525 .

140 Wolfram, supra note 5 , at $667-725$.

141 Id.

142 GARNER, supra note 134 , at 127. 
Under this reading, whether the Seventh Amendment guarantees a jury trial in a civil case depends upon the source of the legal right. If the legal right at issue is one the legislature has created by the passage of a statute, then the Seventh Amendment does not guarantee a civil jury trial. But, if the legal right at issue is one that has been developed by the courts through the evolving judge-created common law, then the Seventh Amendment guarantees a civil jury trial.

This interpretation does not mean that juries can never participate in the adjudication of statutory rights and obligations. Rather, that decision is left to the legislature. It is a decision that is not significantly different or more difficult than other similar decisions implicit in such legislation. Whenever a legislature passes a statute, it is faced with at least two threshold questions. First, should there be a private cause of action? Second, should disputes involving that cause of action be tried before a court or an administrative agency? Under the proposed definition of "in suits at common law," the legislature would address a third issue in the inquiry: If there is a private cause of action triable in the courts, should there be an entitlement to a jury trial?

This interpretation of the phrase "in suits at common law" is entirely in harmony with the intent of the Seventh Amendment. As discussed above, at least part of the intent of the Anti-Federalists in demanding the amendment was to provide a check on the power of the sovereign. ${ }^{143}$ That check is obviously present where there has been a legislative enactment of statutory rights. In the unlikely event that the population as a whole believed that the legislature was oppressively creating or abolishing rights, it could exercise its right to vote the rascals out. There is no similar check, however, on federal judges with constitutionally-mandated life tenure. While statutory law is a creation of popularly elected representatives answerable to the public on the next election day, juries are the only direct counter-balance to judges. Thus, if the Seventh Amendment indeed reflects a concern over the limits of the power of the sovereign as judge in a federal courtroom, then a fair interpretation of the amendment would be to guarantee the presence of a jury to balance the exercise of authority by the judge.

There are at least two fair criticisms of this interpretation, but neither is fatal. The first is that since Erie v. Tompkins holds that there is no federal general common law, ${ }^{144}$ guaranteeing civil juries only in federal common law cases guarantees little at all. In diversity cases, however, federal judges are often the arbiters of state common law. Thus, a federal judge is often in the business of defining legal rights, and absent a jury there is no mechanism for citizen control. The alternate solution is to empanel juries only according to the rules of the forum state, but, depending on a state's rules, this would again

143 Wolfram, supra note 5 , at 670-72, 708-10.

144304 U.S. 64, 78 (1938). 
create the possibility of a federal judge acting in an unchecked and uncheckable fashion. Thus, the better solution is to guarantee the right to a jury in any civil case in which a federal judge is interpreting non-statutory rights. ${ }^{145}$

Second, while interpreting common law in contradistinction to equity reflects the goals of the drafters, it admittedly may not reflect their specific intent when writing the words "common law." 146 As this Article demonstrates, however, the specific intent of the drafters in writing the words "common law" was not to capture any particular meaning of common law. Making any particular choice meant offending at least twelve states. Thus, the drafters chose this phrase intending it to have no detailed meaning, but rather left the leeway to future generations to craft ways to guarantee civil jury rights. Thus, the real mistake in interpreting "in suits at common law" is to assume the words originally had a specific intended meaning (Justice Story's error), rather than attempting to craft a meaning consistent with the goals of the drafters.

In keeping with the spirit of the drafters, the interpretation proposed here not only comports with the goals of the drafters, but also eliminates the most glaring disadvantage of the historical test-that it has no ability to evolve with changing society. Under this new interpretation, courts and legislatures would be free to decide the size of juries, the degree of unanimity required for decision, the form of instructions or questions put to the jury, the degree to which the jury can be actively involved in asking questions of either the judge, the witnesses, or the lawyers, or any other range of details of jury practice. If there is consensus that a common law question is too complex for a jury, then the legislature can codify that right by statute and simultaneously take away the jury right. If the population as a whole disagrees with this decision, they can elect different legislators. The system can evolve and adapt within the Seventh Amendment, not in spite of it. The Seventh Amendment can be read as the simple instruction that it is: If a legislature creates, by statute, a legal right which heretofore did not exist, the legislature can determine whether trial of that right should be to a jury, but in all other instances a litigant has an absolute right to a jury trial in a civil case in federal court.

Just as the Emperor's new clothes were an illusion, so has been the supposed mandate of the Seventh Amendment under the historical test. For two hundred years, the Emperor has been naked. It is time to put on his coat.

145 If the federal judge is deciding a state statutory right, the entitlement to a jury is the decision of the state legislature.

146 There is no record reflecting that the drafters meant common law in contradistinction to statutory law. 